ppi $201502 Z U 4645$

Esta publicación cientifica en formato digital es continuidad de la revista impresa ISSN-Versión Impresa 0798-1406 / ISSN-Versión on line 2542-3185Depósito legal pp

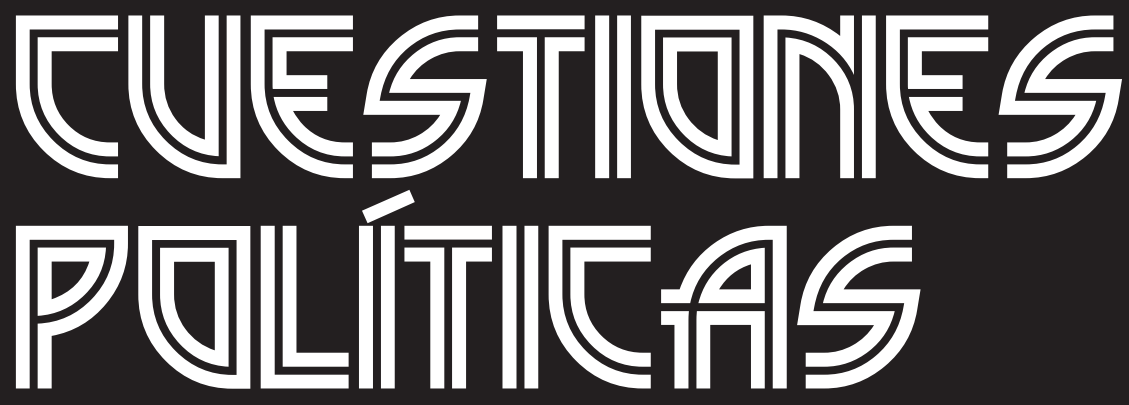

Instituto de Estudios Políticos y Derecho Público "Dr. Humberto J. La Roche' de la Facultad de Ciencias Jurídicas y Políticas de la Universidad del Zulia Maracaibo, Venezuela
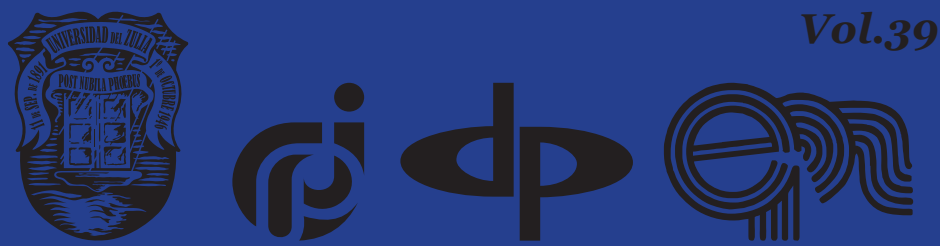


\title{
Reflections on the respect of the rights of citizens during judicial decisions of execution
}

\author{
DOI: https://doi.org/10.46398/cuestpol.3968.35
}

\author{
Nataliia A. Sergiienko * \\ Volodymyr I. Galagan ** \\ Zhanna V. Udovenko *** \\ Andriy P. Cherneha **** \\ Nataliia O. Oblovatska *****
}

\section{Abstract}

The objective of the article was to analyze the problematic aspects of the judicial executive process, considering its properties and the classification of its stages. The methodological basis of the study are the general and special methods of scientific knowledge (inductive, analytical, hermeneutic, systemic and others). The results of the study include the analysis of scientific approaches to the essence, properties, classification of stages of the executive process and argumentation of theoretical proposals and informed practices. Moreover, the authors' conclusions on certain topics are set out, a new original definition of «stages of the executive process" and their original new classification is based. The practical importance of the results is that the conclusions and proposals made significantly enrich procedural science during the implementation of judicial decisions; it will be useful for the subjects of enforcement proceedings (implementing agents, parties to enforcement proceedings) in the exercise of their procedural rights and the performance of their procedural functions. The conclusions presented based on the analysis can be used to generalize executive practice.

* PhD in Law, Senior Lecturer at the Department of Public and Private Law, Borys Grinchenko Kyiv University, Ukraine. ORCID ID: https://orcid.org/oooo-0002-6681-5961. Email: n.sergiienko5514@ politechnika.pro

* Full Doctor in Law, Professor at the Department of Criminal Law and Law of Criminal Procedure, National University of "Kyiv-Mohyla Academy, Ukraine. ORCID ID: https://orcid.org/oooo-ooo18224-0099. Email: galagan@tanu.pro

*** PhD in Law, Assistant Professor at the Department of Criminal Law and Law of Criminal Procedure, National University of "Kyiv-Mohyla Academy", Ukraine. ORCID ID: https://orcid.org/oooo-0oo24100-0723. Email: zhudovenko@uohk.com.cn

****PhD in Law, Assistant Professor at the Department of Public and Private Law, Borys Grinchenko Kyiv University, Ukraine. ORCID ID: https://orcid.org/oooo-ooo1-5016-6998. Email: a_cherneha@nuos. pro

***** PhD in Law, Senior Lecturer at the Department of Public and Private Law, Borys Grinchenko Kyiv University, Ukraine. ORCID ID: https://orcid.org/oooo-0002-7405-279X. Email: oblovatska@tanu. pro 
Nataliia A. Sergiienko, Volodymyr I. Galagan, Zhanna V. Udovenko, Andriy P. Cherneha y Nataliia O. Oblovatska

Keywords: judicial executive process; stages of the executive process; attributes of the stages of the executive process; classification of the stages of the executive process; active citizenship.

\section{Reflexiones sobre el respeto de los derechos de los ciudadanos durante las decisiones judiciales de ejecución}

\section{Resumen}

El objetivo del artículo fue analizar los aspectos problemáticos del proceso ejecutivo judicial, atendiendo sus propiedades y la clasificación de sus etapas. La base metodológica del estudio son los métodos generales y especiales del conocimiento científico (inductivo, analítico, hermenéutico, sistémico y otros). Los resultados del estudio incluyen el análisis de aproximaciones científicas a la esencia, propiedades, clasificación de etapas del proceso ejecutivo y argumentación de propuestas teóricas y prácticas fundamentadas. Por lo demás, se exponen las conclusiones de los autores sobre ciertos temas, en particular, una nueva definición original de « etapas del proceso ejecutivo y se fundamenta su nueva clasificación original. La importancia práctica de los resultados es que las conclusiones y propuestas formuladas enriquecen significativamente la ciencia procesal durante la ejecución de las decisiones judiciales; será de utilidad para los sujetos de los procedimientos de ejecución (en particular, los agentes de ejecución, las partes en los procedimientos de ejecución) en el ejercicio de sus derechos procesales y el desempeño de sus funciones procesales. Las conclusiones presentadas con base en el análisis se pueden utilizar para generalizar la práctica ejecutiva.

Palabras clave: proceso ejecutivo judicial; etapas del proceso ejecutivo; atributos de las etapas del proceso ejecutivo; clasificación de las etapas del proceso ejecutivo; ciudadanía activa.

\section{Introduction}

There are many reforming processes in Ukraine just now. One of them is the reform of executive process. Introduction the institute of private executors, improving the procedure of executive process, making this process clearer are only one of remedies that have already been done during the transformation of executive process of Ukraine. Is it mean that Ukrainian executive process has become excellent? Not at all, but just now 
we can see the progress in this sphere. For example, in some cases creditors can choose the system of compulsory execution: either governmental system of compulsory execution or private system of compulsory execution. If the creditor has chosen private system of compulsory execution, he $\backslash$ she can choose private executor inside the executive district. This factor stimulates the rivalry between governmental system of compulsory execution or private system of compulsory execution, telling exactly, between governmental executors and private executors. This fair rivalry is determined by The Strategy of Reformation the Judicial System, Judgement and Adjacent Legal Institutes for 2015-2020 (approved by the Order of the President of Ukraine № 276/2015 20.05.2015). This remedy is one from the list of effective remedies for reorganization the system of court decisions execution and improving the effectiveness of executive process.

Among these remedies also as follows: assembling solid mechanism of functioning the system of compulsory execution bodies; development of private executors institute, especially because of stating gradual system of self-government, the mechanism of entering the profession; implementation the system of control under the activity of private executors, implementation the insurance of professional civil responsibility of private executors; abidance the balance between the competence of governmental executors and private executors; revision of the mechanism of forming the remuneration of executors for stimulating rising the real execution of court decision; optimization of stages of executive process and terms of making executive acts etc.

The effectiveness of the protection of violated rights, freedoms, interests of persons mediated by the decision of the relevant jurisdiction is directly related to its implementation. In the vast majority of cases, these are court decisions, most of which involve enforcement. In particular, under Part 2 of Article 21 of the Criminal Procedure Code of Ukraine, a sentence and court decision that have entered into force in the manner prescribed by this Code are binding and subject to unconditional execution throughout Ukraine. Other procedural codes are also binding on the court. Meanwhile, the adoption of a court decision and its further implementation is carried out by different entities (respectively - the court and the executors), not subordinate to each other, moreover - it happens in different jurisdictions (for example, a court decision can be made in civil, criminal, administrative, commercial litigation, and its implementation - within the enforcement proceedings). The actual and direct restoration of violated rights, freedoms, interests is connected with the execution of a court decision, so it is difficult to overestimate its significance in the mechanism of their restoration (The case of Hornsby v. Greece, 1997; The case of Romashov v. Ukraine, 2004; The case of Yuriy Mykolayovych Ivanov v. Ukraine, 2009). 
Nataliija A. Sergiienko, Volodymyr I. Galagan, Zhanna V. Udovenko, Andriy P. Cherneha y Nataliia O. Oblovatska

As a jurisdictional process, the enforcement process has its stages. At the same time, in the scientific and methodological literature the term "stage" is mostly used for procedural branches (criminal procedural, civil procedural, economic procedural, etc.) usually associated with the term "process", in particular, civil process stages, economic process stages (Fursa et al., 2008). It is difficult to talk about the relevant jurisdictional process, bypassing its stages. This appears to be related to temporal (temporal) and substantive unity and the simultaneous differentiation of the relevant jurisdictional process. Procedural stages are, according to Shcherbak (2011), a characteristic of the dynamics of the legal process. Stages of enforcement proceedings, continues this author, form a structurally determined sequence of enforcement actions, which reflects the progress of the requirements of the enforcement document, and the separation of logically related stages.

Of course, staging is closely related to a certain sequence of actions, so it is a question of a certain chronology of actions - which action follows. However, it would be premature to ignore the fact that staginess, in addition to the temporal dimension, also has a substantive dimension - the content of the acts themselves that must / may be committed during enforcement, and the vector dimension - the commission of such acts has a specific direction, and it is to achieve the solution of certain tasks in the appropriate time (for example, sending the executor requests for the presence of the debtor's property is aimed at solving the problem of finding such property, which will later be able to recover).

\section{Methods}

The methodological basis of the study is a system of general and unique methods of scientific knowledge, which allowed to fully and comprehensively explore the topic of the article, to achieve the goal of this study. The inductive method allowed to separate the main issues of the topic from the array of discussion aspects of the modern executive process. With the help of this method of scientific knowledge, the main scientific works of legal scholars who study this issue were selected. The analytical method allowed to identify the state of scientific development of the topic, the main scientific approaches to the concept of stages of the executive process, their properties, classification. The method of analysis revealed the most substantiated theses in the scientific developments of legal scholars who study the problems of the executive process, which was laid in the theoretical basis of this scientific article.

The analysis of scientific works, which cover the topics of the executive process, allowed to have a reasoned scientific discussion during the writing of the work - taking into account existing developments to formulate their 
conclusions and judgments on this issue. Also, the method of analysis allowed to identify the properties of the stages of the executive process. The hermeneutic method of scientific cognition made it possible to comprehend the prescriptions of the main legal acts, judicial practice on the subject of the stages of the executive process. With the help of this method, the main gaps in the legislation governing the scope of the enforcement process were identified.

The systematic method of scientific cognition was used in interpreting the provisions of regulations governing the stages of the executive process, forming comments on the wording of such regulations and proposals to improve the legal regulation of the stages of the executive process. With the application of the systematic method of scientific cognition, conflicts were revealed in the normative-legal regulation of the sphere of the executive process, in particular, its stages. This method made it possible to formulate the conclusions of scientific work, in particular, in the context of the proposed author's classification of stages of the executive process.

The comparative method of scientific knowledge was used in elaborating the views of legal scholars on the concept of stages of the executive process and its classifications. The method of synthesis made it possible to generalize the most common in the science of the executive process approaches to determining the stages of the executive process, their classification. In particular, with the help of this method, it was summarized that the most common classifications of stages of the executive process are classifications with four elements of such stages. The modelling method was used in the formation of its concept of classification of stages of the executive process. This method allowed to form the author's model of classification of stages of the executive process: with its division into contextual stages, substantiation of the separateness of each stage, and, at the same time, with substantiation of close inseparable connection of all stages of the executive process reflecting internal integrity and dynamism of executive process as phenomena. The application of this method made it possible to propose a new original author's model of classifications of stages of the executive process.

The dialectical method of scientific cognition was used, most of all, in the study of classifications of stages of the executive process. It allowed to study the structure of each stage of the executive process in its unity with the task of the corresponding stage and its inseparable connection with other stages of the executive process. The application of the dialectical method of scientific cognition was reflected, inter alia, in the study of the stages of the executive process as a dynamic and multifaceted legal phenomenon. This method was used in the study of the properties of the stages of the executive process and made it possible to explore and propose a new conceptual view of their structural and elemental composition. 
Nataliia A. Sergiienko, Volodymyr I. Galagan, Zhanna V. Udovenko, Andriy P. Cherneha y Nataliia O. Oblovatska

\section{Results and Discussion}

\subsection{The concept of "stage of the executive process"}

Examining the concept of "stage of enforcement proceedings", it should be noted that the term "enforcement proceedings" and its categorical apparatus are currently in the process of formation. Ihonin (2007) under the stage of enforcement proceedings understands a set of interdependent procedural actions of the subjects of enforcement proceedings aimed at achieving a certain stage goal regarding the enforcement of enforcement documents. It is worth agreeing with the position of this scientist on the essential reduction of the stages of enforcement proceedings to the procedural actions of its subjects. Instead, the statement that such actions are interdependent is subject to critical consideration, because 1) the legislation on enforcement proceedings does not always prerequisite the performance of the relevant enforcement proceedings by a particular subject of enforcement proceedings another enforcement action of the same or another subject of the process; 2) a significant number of such actions may or may not be committed at the will of the subjects of enforcement proceedings, as they are related to the exercise of their rights. For example, the claimant has the right to submit a written request for the return of the enforcement document without enforcement, exercising his right without prior correlation with the procedural actions of other subjects of enforcement proceedings. These actions and decisions can be fully considered as a manifestation of dispositiveness in the executive process.

For these reasons, the proposal of S. Fursa and S. Shcherbak to consider the stages of enforcement proceedings through a set of actions of certain entities, according to which the stage of enforcement proceedings should be understood as a set of procedural actions of the state executor, other subjects of enforcement proceedings aimed at achieving a certain procedural goal (Fursa and Shcherbak, 2002). However, if the substantive component of the stages of the enforcement process, which is formed by certain actions of its respective subjects aimed at achieving the relevant goal, is properly reflected in the above definition, then to fully understand the concept of stages of enforcement proceedings their chronological aspect is the sequence of such actions in time.

The executive stages of this, writes Makushev (2017), are certain internal results, but they always remain their own, separated by one of the simultaneous decisions that adhere to a certain set, which is implemented, and have to adhere to important results. If suggested, on the other hand, this study very aptly emphasized that the stages were performed by the power of a certain known one of the other, which is constantly changing in the process. The language can be solved by publishing a written letter (a decision confirming the decision made by confirming the text is recorded in the paper), as the decision is not formally used (required to address the 
need for making records for a variety of property on the jacket an arrest must be made, and he considers that the legislation that is not used has been complied with in the relevant documents).

At the same time, from the aspect of the criminal process, it is necessary to ask the question about the most common term "stage", which is performed during the work, which is exposed to itself, when it is necessary to make a separate stage during the analysis. In particular, in the legislation of Ukraine and the theory of criminal procedural law, the term "stadium" exists only concrete and detailed: it is a select place that has to be used by inherent users and they serve known prices and used tomorrow criminal trust (Tatsii et al., 2013); using only those that, also, are different stages of criminal proceedings, adhering to trusted actions, specialized circles of subjects who must comply with the form and summarizing the decision (Kovalenko et al., 2013).

To address the relationship between the concepts of "stage" and "stage", it is advisable to be guided by their content load. In the Great Explanatory Dictionary of the modern Ukrainian language, the concept of "stage" is defined as a certain moment, period, stage in life, development, which have qualitative features (Busel, 2003). One of the meanings of the term "stage" is a separate part of something (Busel, 2003). Therefore, we believe that it is appropriate to define the stage as a separate period of proceedings, which includes the execution of court decisions. Instead, certain areas of such enforcement should be defined as stages aimed at achieving the objectives of enforcement proceedings. However, in the science of the executive process, civil, administrative processes is more commonly used to apply the concept of stages of these processes. Because of the above, we propose to continue to talk about the stages of the executive process. Given the above, it seems reasonable to define the concept of "stage of the executive process" as a set of procedural actions of the subjects of the executive process (subject aspect), aimed at performing certain (certain) situational (situational) tasks (tasks) within the executive process (vector aspect), occurring in the appropriate sequence (time aspect).

\subsection{Properties of stages of the executive process}

In essence, the stages of the enforcement process consist of procedural actions of its subjects, which have / can be committed during the enforcement of decisions. In defining them, the vast majority of scholars reduce them to the actions of the subjects of enforcement proceedings. Of course, their actions meaningfully fill each of the areas of this activity. However, an important component is the inaction of their subjects in accordance with the requirements of the law on enforcement proceedings. For example, the unconditional obligation of the debtor to refrain from actions that make it 
Nataliịa A. Sergiienko, Volodymyr I. Galagan, Zhanna V. Udovenko, Andriy P. Cherneha y Nataliia O. Oblovatska

impossible or difficult to enforce the decision (paragraph 1 of part 5 of Article 19 of the Law of Ukraine "On Enforcement Proceedings" (On Enforcement Proceedings, 2016) will be inherent in the direct enforcement of property (e.g., property search - no to hide property, not to destroy it, etc.; similarly, during its description and arrest - not to damage such property, etc.). If we analyse the whole procedure of enforcement of decisions, we can find that in general it is built on the principle of its observance by all parties, which implies that they do not take action to violate it. And in case such a violation still took place (inaction is not observed), the law provides for a compensatory mechanism.

For example, the law does not contain an obligation for the debt collector not to interfere with the enforcement agent in carrying out enforcement actions. However, the provisions of paragraph 4 of part 1 of Article 47 of the Law of Ukraine "On Enforcement Proceedings" determine that if the claimant still commits such actions, the executor will return the enforcement document without execution. Therefore, throughout the enforcement proceedings, the claimant has, in effect, a duty of inaction to prevent the enforcement agent from carrying out enforcement actions. Similarly, it is possible to speak if the debtor interferes with the execution of the decision on his eviction - the state executor imposes a fine on him in the manner prescribed by part 6 of Article 66 of the Law of Ukraine "On Enforcement Proceedings" (here the compensatory mechanism is just such a fine). Actions that are the subject of the relevant stage of the enforcement process are characterized by the fact that they: a) must be performed by the relevant subjects in terms of performance of procedural duties); or b) may be committed at one time or another during the enforcement of decisions (it is a question of realization of the corresponding procedural rights by separate subjects of executive proceedings), or c) essentially provide inaction.

Within the stages of the enforcement process perform certain situational tasks, to achieve which the subjects of enforcement proceedings take appropriate actions / refrain from them. Thus, the implementation of such tasks is a kind of vector of action of these actors (vector aspect of the stages of the executive process). Subject aspects of the stages of the executive process are determined by the tasks to be performed on the timeline of the executive process. The situational of the tasks is that they are relevant to the solution for the appropriate stage of the executive process. This can be illustrated by the following example. Before initiating enforcement proceedings, it is first necessary to decide whether such a process will be initiated at all: whether there are factual and legal grounds for enforcement of a particular decision by the authorized entity to which it is enforced, or whether there are obstacles. The solution of the specified task is actual at the presentation of the executive document to compulsory execution. 
After establishing that the executive document meets all the requirements specified by law, the decision based on which it was issued, is enforceable and has entered into force, there are no obstacles to enforcement (for example, no delay), the executive document submitted by the subject, authorized to present it for enforcement, the executive document presented in compliance with the requirements of the law for the enforcement of the entity authorized to carry out such enforcement, the executor will open enforcement proceedings. However, it may also be established that the factual and / or legal grounds for the enforcement of a particular decision by the entity to which it is presented for enforcement are absent or there are obstacles to enforcement.

If the enforcement document is presented for enforcement, does not meet the requirements of the law for enforcement documents or enforcement of the decision does not provide for enforcement measures, the enforcement document will be returned to the claimant without acceptance for enforcement, and enforcement proceedings will not be opened. However, even in this case, there is a legal relationship of enforcement proceedings between the executor and the applicant. Given the above, the first stage of the enforcement process is to determine the presence of the enforcement document for enforcement, as the opening of enforcement proceedings may not occur after the presentation of the enforcement document for implementation (the enforcement document may be returned to the claimant without acceptance).

The stages of the executive process are characterized by a certain time sequence. This is due, firstly, to the fact that the procedure for enforcement proceedings is determined by law, and secondly, the time sequence of actions by the subjects of enforcement proceedings is characterized by logic (for example, first you should open enforcement proceedings, and then directly enforce decisions; you need to find the property and then evaluate it). The temporal measurement of the stages of the executive process is the sequence of performance of the relevant actions by the authorized subjects of the executive process, therefore, it is a question of a certain chronology of actions and determination of the procedure for carrying out the necessary actions.

\subsection{Classification of stages of the executive process}

Examining this question, Shcherbak (2011) notes that there are two grounds for classifying the stages of the legal process: functional and logical. According to the functional classification, it distinguishes the stages of violation of the legal process, preparation for consideration, consideration of the case and decision-making based on the results of consideration of the case. The logical classification of stages plays a similar functional but 
Nataliia A. Sergiienko, Volodymyr I. Galagan, Zhanna V. Udovenko, Andriy P. Cherneha $y$ Nataliia O. Oblovatska

slightly different role and traditionally has the following stages: clarification of the facts of the case; clarification and determination of the rule of law to be applied; making a decision based on the results of these two stages (Shcherbak 2011). The application of such a classification seems justified to the stages of the executive process. However, they are characterized by both functional (demonstrates the movement of the process from its beginning to completion) and logical (shows the rationale for the content of each component of enforcement proceedings) classification.

In the legal literature, the most common classifications of stages of enforcement proceedings are four-component classifications. Fursa and Shcherbak distinguish among them: the opening of enforcement proceedings, preparation for execution, taking enforcement measures against the debtor, the final (Fursa and Shcherbak, 2002). Similarly, Bilousov (2005) also notes the four components of the levels of enforcement proceedings: the opening of enforcement proceedings, preparation for enforcement, taking measures to enforce the decision, the end of enforcement proceedings. Sometimes you can find another classification:

1) the opening of enforcement proceedings.

2) enforcement proceedings.

3) completion of enforcement proceedings.

4) appeal against decisions, actions, or inaction of officials of the State Executive Service (Kalinin, 2013). It seems that the latter component should be considered rather as a complication in the legal relationship of enforcement proceedings, as an appeal can take place at any stage of the enforcement process as a guarantee of the rule of law and legality of enforcement proceedings.

Instead, Ihonin (2007) adheres to a three-part structure and notes the opening of enforcement proceedings; enforcement proceedings; the final stage of enforcement proceedings. A significant number of scholars express the position that the first stage of enforcement proceedings is its discovery. However, this statement cannot be fully accepted for several reasons. First, as it was substantiated earlier, before initiating enforcement proceedings it is necessary to apply to the ICE body/person acting in its interests with a request to initiate enforcement proceedings for enforcement of the decision, which is the basis for specific procedural legal relations between such applicant, on the one hand, and the subject of enforcement, on the other.

Such legal relations are not always transformed into legal relations between the debt collector and the executor, as enforcement proceedings may not be opened, in particular, if the enforcement document is returned to the debt collector without acceptance for execution. Therefore, the initial 
stage of the enforcement process, in our opinion, should be determined by the presentation of the enforcement document for enforcement, and not the opening of enforcement proceedings.

Secondly, there are views that the civil process can begin with the submission of a statement. For example, in the work of Komarov (2011) and some other scholars gave one of the classifications of stages of civil proceedings, the first of which is the stage of applying to the court. Here it is appropriate to conclude Yu. Osipov (1978) that the application of civil procedural law, as well as the rules of any branch of law, in terms of the internal logic of this activity, includes three main elements of law enforcement: establishing the facts of a particular procedural situation, which allows to apply this or that norm of civil procedural law; selection and analysis of the applicable law; authoritative decision of the procedural issue, application of the relevant rule of law and adoption of a judicial act. Therefore, at any stage of the jurisdictional process, including enforcement, the relevant subject will establish the facts of the case, which allows the application of the relevant rules of law, the choice of such rules, their application and appropriate registration of such application of the law. This correlates with the logical classification of stages of the legal process, as discussed earlier.

Third, in the legal literature, the opening of enforcement proceedings is not always considered solely as a stage of enforcement proceedings. For example, Krupnova (2017) defines the opening of enforcement proceedings as an administrative procedure, which itself has its stages. However, when analysing the filing of an application for the opening of enforcement proceedings, it would be erroneous to claim that there is a factual confirmation of the validity of the claims of the debt collector, as well as the obligations of the debtor (Krupnova, 2017), as the question of the validity of the claims of the person named as the debt collector in the enforcement document in respect of the person listed there as a debtor, arises when making a decision, which should then be enforced.

It seems that when presenting an executive document for enforcement, the main task is to establish whether there are factual and legal grounds for enforcement of a particular decision by the entity to which it is addressed. In the absence of such grounds for enforcement of a particular decision, the subject to whom it is presented for enforcement, as well as in the presence of obstacles to enforcement will be grounds for returning the executor of the executive document without acceptance for execution, the executor makes a decision. Under such conditions, it is further a question of completion of enforcement proceedings. On the contrary, in establishing the existence of factual and legal grounds for enforcement of a particular decision by the entity to which it is presented for enforcement, the absence of obstacles to enforcement will be grounds for initiating enforcement proceedings. 
Nataliuia A. Sergiienko, Volodymyr I. Galagan, Zhanna V. Udovenko, Andriy P. Cherneha y Nataliia O. Oblovatska

560

Reflections on the respect of the rights of citizens during judicial decisions of execution

The opening of enforcement proceedings takes place subject to the establishment of legal and factual grounds for enforcement upon presentation of the enforcement document for enforcement. Meanwhile, it would be premature to claim that the stage of the enforcement process is limited solely by the issuance of the enforcement order to initiate enforcement proceedings. It should be emphasized that the decision to initiate enforcement proceedings is both one of the documents that finalizes the first stage - the presentation of the enforcement document for enforcement and begins the next - the actual opening of enforcement proceedings.

The above characterizes the progressive stages of the enforcement process and its integrity as a jurisdictional activity. From this moment the executor necessarily enters in the Automated system of executive proceedings information on carrying out of all executive actions and acceptance of procedural decisions as before actually it was a question of registration in this system of incoming and outgoing correspondence, and before the opening of executive proceedings it was not known at all. , whether it will be opened or the executive document will be returned to the claimant without accepting it for execution (Order Of The Ministry Of Justice Of Ukraine, 2016).

Characterizing the opening of enforcement proceedings, T. Minka and several other scholars note that its content is to send the executor of the relevant resolution on the opening of enforcement proceedings, including the parties (Minka, 2017). In fact, according to Article 28 of the Law of Ukraine "On Enforcement Proceedings", the executor notifies the parties of the decision to initiate enforcement proceedings and takes immediate priority measures that will make possible / more effective further enforcement. In particular, it is a question of seizing the debtor's funds, if the debtor's statement indicates the debtor's accounts in banks and other financial institutions; checking in electronic state databases and registers the existence of property rights or other property rights of the debtor to the property and seizure of it, if the statement of the collector indicates the specific property of the debtor (part 7 of Article 26 of the Law of Ukraine "On Enforcement Proceedings"). It should be noted that until there is a full search for the debtor's property, the executor only takes immediate priority measures for the property, which he was notified by the debt collector, related to further enabling/increasing the efficiency of enforcement proceedings.

Taken together, it is reasonable to state that during the opening of enforcement proceedings its main task is to establish an information and security basis (to inform the parties that the execution of the decision has already begun, to take immediate measures to ensure it) further enforcement. However, it is difficult to determine the documents that 
would summarize the results of these actions regarding the commencement of enforcement proceedings, as there may be many of them depending on the categories of enforcement proceedings.

For example, they may be decisions of the executor on the seizure of the debtor's property, which was announced by the debt collector in the application for enforcement proceedings: at the same time, these documents will be final for the stage of opening enforcement proceedings and mark the beginning of the next stage - security. to describe and arrest him. Instead, in several cases, the legislation does not provide for the execution by the executor of separate procedural documents to complete the actions aimed at initiating enforcement proceedings. For example, during the execution of decisions on eviction of the debtor, the decision to initiate enforcement proceedings must indicate the need to execute the decision within 10 working days, after which the execution must be verified.

During the precautionary stage of the enforcement process, conditions should be created for further enforcement, depending on the category of enforcement proceedings and specific enforcement proceedings. For example, to ensure further recovery from the debtor in favour of the debt collector should be carried out: search for the debtor's property, including his money, property/money belonging to the debtor from others; determining whether the foreclosure can be made on this property; valuation of such property/determination of its value; resolution of other issues on which further effective enforcement depends (for example, resolution of the issue of determining the debtor's share in the property that is jointly owned by the debtor and other persons), etc. A significant part of scientists defines these procedural actions as preparation for enforcement (Fursa and Shcherbak, 2002; Shcherbak, 2011).

For example, Yu. Bilousov (2005) refers to the preparation for the enforcement of the actions of the state executor, aimed at establishing the place of residence of the debtor, his work, finding out the amount of wages, proposals to execute the decision voluntarily, creating conditions for further execution of the decision, including compulsorily. At the same time, taking into account the definition of enforcement proceedings given in Article 1 of the Law of Ukraine "On Enforcement Proceedings" (where enforcement proceedings are defined in essence as enforcement) and the provisions of Article 26 of this Law on enforcement, we note that all enforcement proceedings is a process of enforcement. Therefore, it seems that the stage of the enforcement process at which the task of ensuring the implementation of further specific measures to implement the decision, provided by the executive document, should be called accordingly - security.

After that, it is quite possible to move to the completion of enforcement proceedings. Such a situation may arise when the debtor has no property that can be recovered, the measures taken by the executor to search for him 
Nataliia A. Sergiienko, Volodymyr I. Galagan, Zhanna V. Udovenko, Andriy P. Cherneha $y$ Nataliia O. Oblovatska

were ineffective to the debt collector. The final documents for this stage of the executive process are quite diverse. For example, they may be: decisions of the executor on the description and seizure of the debtor's property, on the seizure of the debtor's property, which he found in response to the competent authorities/persons to the executor's inquiries regarding the debtor's property; resolutions of the state executor, by which he informs the debtor about the day and time of forced eviction determined by him (Article 66 of the Law of Ukraine "On Enforcement Proceedings". Although the legislative provisions do not mention the need to make a decision forced eviction, he informs the debtor with the appropriate resolution).

\subsection{Formation of a holistic and effective enforcement process}

The task of the stage of direct enforcement is to take direct measures to enforce the decision. It is worth agreeing with the definition of enforcement measures proposed by I. Zelenkova (2017), which she means the powers of the executor to enforce the decision provided by law, as well as measures to influence the debtor, which should encourage him to enforce the decision and not create obstacles to it performance. Indeed, on the one hand, the direction of such measures is clearly defined - enforcement. On the other - the emphasis is on the fact that it is also a measure of influence on the debtor, because sometimes without them it is impossible to talk about the effectiveness of enforcement. The provisions of Article 10 of the Law of Ukraine "On Enforcement Proceedings" determine the types of enforcement measures. However, this list is supplemented by the blanket norm of paragraph 5 of part 1 of Article 10 of the same Law, which refers to other forms of the Law of Ukraine "On Enforcement Proceedings", without detailing them. Therefore, there is a need to determine whether certain measures taken by the executor belong to the measures of enforcement of decisions.

As an example of resolving this issue, we will consider foreclosure on funds, securities, other property (property rights), corporate rights, intellectual property rights, objects of intellectual, creative activity, other property (property rights) of the debtor as enforcement measures. Part 1 of Article 48 of the Law of Ukraine "On Enforcement Proceedings" stipulates that such treatment of the debtor's property consists in his arrest, seizure (write-off of funds from accounts) and enforcement.

The fact that the seizure of the debtor's property is defined in the context of foreclosure, namely foreclosure - as a measure of enforcement, does not mean that security actions during enforcement proceedings (namely in this context, property seizures were previously considered) merges with direct enforcement. First, the seizure of the debtor's property may be precisely the measure to be taken in enforcement proceedings, i.e. the direct subject of 
enforcement in the case of enforcement of a court order securing a claim by seizing the debtor's property. Secondly, the stages of the executive process are progressive and form a holistic inseparable process - the end of one stage at the same time can mean the beginning of the next.

To form a holistic and effective enforcement process, it is possible to superimpose them on each other, for example, if part of the debtor's property has already been found, assessed within the security stage and transferred for sale (this is direct enforcement), however, it is obvious that due to the sale of the property it will not be possible to satisfy all the requirements of the debt collector, to collect the enforcement fee, etc., then there should be a parallel search for other property of the debtor, assessment of the found property. Here we see flexibility in the question of the unity of the stages of the enforcement process, which is fully correlated with the need for full, timely and impartial execution of the court decision.

Withdrawal of property (write-off of funds from accounts), forced sale of the property is characterized as direct enforcement, in particular, in the case of execution of decisions to recover in favour of the debt collector from the debtor: this can happen by writing them off from the debtor's bank accounts (if the executor such accounts identified and available funds), and by seizing the property and transferring it for sale to third parties with the subsequent direction of proceeds from the sale first to the account of the executor / State Enforcement Service, and from him - the collector and the executor/body of the State executive service.

There are a significant number of final documents, depending on the category and specific enforcement proceedings, that would finalize this stage of the enforcement process. For example, this may be an act of electronic bidding on which the property is sold; decision on the transfer of property to the debt collector to repay the debt and the act of such transfer, if the debt collector agreed to receive at the expense of debt repayment property that was not sold in electronic bidding. Based on whether and to what extent enforcement measures have been taken and their results. The executor must establish whether direct enforcement of the decision has been carried out. However, even if for some subjective (for example, the claimant interferes with the execution of the decision) or objective (when the enforceable court decision is revoked) reasons for direct enforcement did not lead to its actual full execution, it is not always appropriate to continue enforcement proceedings. Therefore, it is worth talking about the completion of the enforcement process.

According to R. Kalinin (2013), the completion of enforcement proceedings is the final stage of enforcement of decisions of jurisdictional bodies, covering three types of administrative procedures: the procedure for terminating enforcement proceedings, the procedure for returning the enforcement document to the court or other body (official) that issued it, 
Nataliia A. Sergiienko, Volodymyr I. Galagan, Zhanna V. Udovenko, Andriy P. Cherneha y Nataliia O. Oblovatska

and the procedure of returning the executive document to the collector, the purpose of which is the adoption of the state executor as a subject of public administration of an individual administrative act - a resolution to terminate the enforcement proceedings or return the executive document (Kalinin, 2013).

The last proposed statement related to the drafting of the relevant resolution cannot be fully agreed within view of the following. Firstly, the adoption of the relevant document should be considered as the finalization of the relevant stage of the executive process, a formal generalization of the state of achievement of the objectives of each of them. Secondly, the executor during the enforcement proceedings does not solve the task of accepting certain documents as an end in itself. Depending on the tasks of each stage of the enforcement process that need to be solved (for example, during the direct enforcement - taking measures to enforce the decision), the finalizing documents summarize the status of their implementation.

Also, the return of an enforcement document without enforcement at the request of the court or other body (official) that issued it is the basis for the termination of enforcement proceedings, therefore, should be considered in this context. In this regard, the provisions of Part 1 of Article 40 of the Law of Ukraine "On Enforcement Proceedings", which refer to the termination of enforcement proceedings, and separately - the return of the enforcement document to the court that issued it, although its return without execution at the request of the court or other body (official) that issued the enforcement document is one of the grounds for termination of enforcement proceedings (paragraph 10 of part 1 of Article 39 of the Law of Ukraine "On Enforcement Proceedings"). At the final stage, the executor decides on the termination of enforcement proceedings depending on the circumstances of the case (Fursa and Shcherbak, 2002).

It seems that the task of this stage of the enforcement process is relatively final establishment of the achievement of the general task set before the enforcement body / private executor - full, timely, impartial enforcement of the decision, or impossibility to achieve it for one reason or another; taking measures related to the completion of enforcement proceedings (lifting of arrests, etc.). Therefore, we are talking about the following possible procedural actions:

1. Return of the executive document to the debt collector without acceptance for execution. This correlates with the first stage of the enforcement process, if it was established the absence of factual and legal grounds for enforcement of a particular decision by the entity to which it is presented for enforcement, the presence of obstacles to enforcement (for example, if for objective or objective reasons it is impossible to initiate enforcement proceedings). The grounds for returning the executive document to the claimant without acceptance 
for execution are provided by Articles 4, 5 of the Law of Ukraine "On Enforcement Proceedings", the executor shall issue a relevant resolution.

2. Return of the writ of execution to the debt collector takes place if due to subjective (for example, the debt collector prevents enforcement actions) or objective (for example, the debtor has no property specified in the writ of execution, which he must transfer to the debt collector in-kind) the proceedings can no longer continue, but the tasks facing the enforcement body - timely, complete, impartial enforcement of the decision - remained unfulfilled/incomplete. In this context, it is correct to note S. Fursa, E. Fursa, S. Shcherbak, that the collector is returned the executive document, which was accepted by the state executor for execution, for which the recovery was not carried out or was carried out in part (Fursa et al., 2008).

Yu. Bilousov (2005) notes that the return of the executive document to the claimant - a form of termination of enforcement proceedings without execution of the decision, according to which the recovery was not carried out or was carried out in part on the initiative of the collector to implement the principle of dispositiveness. However, this statement cannot be fully accepted, as the termination of enforcement proceedings is an independent type of completion of enforcement proceedings, has its grounds, among which the return of the enforcement document to the claimant is absent. The grounds for returning the executive document to the claimant are provided by Article 37 of the Law of Ukraine "On Enforcement Proceedings", the executor shall issue a relevant resolution on such a decision.

3. Completion of enforcement proceedings. Although Article 39 of the Law of Ukraine "On Enforcement Proceedings", which defines the grounds for termination of enforcement proceedings, refers to "termination", it is worth agreeing with the position of several scholars proposing to replace the term "termination" with "closure". apply terminology that has a wider application in practice and is used in other similar regulations, such as the Civil Procedure Code (Fursa et al., 2008).

Not only in the Civil Procedure Code of Ukraine, but also the Commercial Procedural Code of Ukraine, in the Code of Administrative Procedure of Ukraine, in the Criminal Procedure Code of Ukraine in this particular case operate the concept of "closing" proceedings, not "termination". Bilousov (2005) defines the termination of enforcement proceedings as an act of the state executor, which consists in the completion of enforcement actions in a certain enforcement proceeding, according to a certain executive document. Indeed, at the end of the enforcement proceedings, the enforcement actions are completed, but they are also completed when the enforcement document is returned to the debt collector. It seems that the main difference 
Nataliuia A. Sergiienko, Volodymyr I. Galagan, Zhanna V. Udovenko, Andriy P. Cherneha y Nataliia O. Oblovatska

between the return of the writ of execution to the claimant and the end of the enforcement proceedings, in addition to the various grounds for each of these types of termination of enforcement proceedings, is as follows.

Upon return of the enforcement document to the claimant, he has the right to re-submit the enforcement document for execution within the period of submission of enforcement documents for enforcement, i.e., enforcement proceedings may be reopened; Enforcement proceedings, which were completed by returning the enforcement document to the debt collector, may be resumed if the executor's decision to return the enforcement document to the debt collector is declared illegal by the court or revoked. Instead, for completed enforcement proceedings, the law does not provide for the possibility of re-initiating its commencement; completed enforcement proceedings may be resumed only if the enforcement order is terminated or annulled by the court (see Articles 37 and 41 of the Law of Ukraine "On Enforcement Proceedings"), as well as in cases expressly provided by law. The grounds for termination of enforcement proceedings are determined by Article 39 of the Law of Ukraine "On Enforcement Proceedings", the executor shall issue a relevant resolution.

However, in several cases provided by law, the end of enforcement proceedings occurs without full actual execution of the decision and contains a precursor to the possible beginning of another jurisdictional process criminal. In particular, the provisions of Article 63 of the Law of Ukraine "On Enforcement Proceedings" provide for the procedure of execution of decisions under which the debtor is obliged to take certain actions or refrain from committing them: the debtor is given a period of execution, after which the executor checks If the debtor does not execute the decision without good reason, the executor imposes a fine on the debtor, demands execution of the decision and warns of criminal liability, after which he rechecks the state of execution of the decision by the debtor.

In case of repeated non-execution of the decision by the debtor without valid reasons, if it can be executed without the debtor's participation, the executor sends to the pre-trial investigation body notification of the debtor's criminal offence and takes enforcement measures provided by the Law of Ukraine "On Enforcement Proceedings". In case of non-execution by the debtor of the decision which cannot be executed without participation of the debtor, the executor sends to the body of pre-judicial investigation the notification on commission by the debtor of a criminal offence and decides on the termination of executive proceedings (paragraphs two, third of part 3 of Article 63).

As mentioned earlier, one of the tasks of this stage of the enforcement process is to resolve issues related to its completion, including lifting arrests, excluding information about the debtor from the Unified Register of Debtors, other actions related to the completion of enforcement (e.g. 
termination of search of vehicles). It is worth agreeing with the position expressed in the legal literature, according to which the provisions of the law on the consequences of the completion of enforcement proceedings should be taken in two areas: legal consequences that arise under objective conditions and actions of the state executor necessary to complete enforcement proceedings.

For example, simultaneously with the end of enforcement proceedings and receipt of the relevant resolution, the debtor, whose property was described and remained in his custody, is again considered the owner of such property, and acquires the right to dispose of it in full (Fursa et al., 2008). Given the above, it seems reasonable that the decision to terminate the enforcement proceedings should indicate not only the lifting of the seizure of property (funds), but also the termination of other measures taken during the enforcement of the decision. If for some reason this decision was not specified, the executor has the right to issue a decision as a separate procedural document to terminate the measures taken during the enforcement of the decision.

General issues of the executive process are considered in the scientific works of Fursa, Fursa, Shcherbak (Fursa et al., 2008); Ihonin (2007), Makushev (2017), Bilousov (2005). Some issues of certain stages of the enforcement process are considered in the works of Kalinin (2013) (in particular, the completion of enforcement proceedings), Krupnova (2017) (in particular, the opening of enforcement proceedings). The issues of the procedure of recovery of the debtor's property in the enforcement process were considered by I. Zelenkova (2017). However, some scientific studies of the stages of the executive process through the context of this concept, its properties and classification are almost absent. Which determines the relevance of a scientific article on this topic.

\section{Conclusions}

Because of the above, the concept of "stages of the executive process" can be defined as a set of procedural actions of the subjects of the executive process (subject aspect of the stages of the executive process) aimed at performing certain (certain) situational (situational) tasks (tasks) within the executive process. vector aspect of the stages of the executive process), occurring in the appropriate sequence (the temporal aspect of the stages of the executive process). The properties of the stages of the executive process are that:

1) substantive stages of the executive process consist of procedural actions of the subjects of the executive process, which have / can be committed at one time or another during the enforcement of decisions. 
Nataliia A. Sergiienko, Volodymyr I. Galagan, Zhanna V. Udovenko, Andriy P. Cherneha $y$ Nataliia O. Oblovatska

2) within the stages of the executive process certain situational tasks are performed.

3) the stages of the executive process are characterized by a certain time sequence.

Stages of the enforcement process can be classified as follows:

1) presentation of the enforcement document for enforcement.

2) opening of the executive process.

3) the security stage of the executive process.

4) stage of direct enforcement.

5) completion of the enforcement process.

Stages of the executive process play an important role in ensuring its integrity and effectiveness as a jurisdictional activity, while differentiating this process structurally. At the same time, the executive process may be characterized by complications that significantly affect its dynamics, which will be noticeable in terms of its stages. The results of the research will be useful to procedural scholars, in particular those working on the subject of enforcement proceedings; executors, parties to enforcement proceedings (debtor, debt collector) during the enforcement of decisions. Analytics and generalizations can be used in generalizations of executive practice. The results of the research were tested at law schools, round tables and conferences, master classes.

\section{Bibliographic References}

BILOUSOV, Yurii. 2005. Enforcement proceedings. Precedent. Kyiv, Ukraine.

BUSEL, Viacheslav. 2003. Large explanatory dictionary of the modern Ukrainian language. Perun. Kyiv, Ukraine.

FURSA, Svitlana; FURSA, Yevhen; SHCHERBAK, Svitlana. 2008. Laws of Ukraine "On state enforcement service", "On enforcement proceedings", "On enforcement of decisions and application of the case law of the European Court of Human Rights": scientific and practical commentary. CST. Kyiv, Ukraine.

FURSA, Svitlana; SHCHERBAK, Svitlana. 2002. Enforcement proceedings in Ukraine. Attica. Kyiv, Ukraine.

IHONIN, Ruslan. 2007. Organizational and legal bases of activity of subjects of executive proceedings. National University of State Tax Service of Ukraine. Irpin, Ukraine. 
KALININ, Roman. 2013. "Completion of enforcement proceedings under the legislation of Ukraine as a kind of administrative procedure" In: Bulletin of Zaporizhia National University. Juridical Sciences. Vol. 2, No. 2, pp. 69-75.

KOMAROV, Viacheslav. 2011. Course of civil procedure. Pravo. Kharkiv, Ukraine.

KOVALENKO, Valentyn; UDALOVA, Larysa; PYSMENNYI, Dmytro. 2013. Criminal proceedings. Center for Educational Literature. Kyiv, Ukraine.

KRUPNOVA, Liubov. 2017. "Theoretical and legal characteristics of the stages of the administrative procedure for initiating enforcement proceedings" In: Bulletin of Luhansk State University of Internal Affairs named after E.O. Didorenko. Vol. 3, pp. 123-131.

LAW OF UKRAINE. 2016. On enforcement proceedings, No. 1404-VIII. Available online. In: https://zakon.rada.gov.ua/laws/show/140419\#Text. Consultation date: 17/05/2020.

MAKUSHEV, Petro. 2017. State executive service in Ukraine: administrative and legal research. Zaporizhzhia National University. Zaporizhzhia, Ukraine.

MINKA, Tetiana. 2017. Administrative procedural law. Dnipropetrovsk State University of Internal Affairs. Dnipro, Ukraine.

ORDER OF THE MINISTRY OF JUSTICE OF UKRAINE. 2016. Regulations on the automated system of enforcement proceedings, No. 2432/5. Available online. In: https://zakon.rada.gov.ua/laws/show/z112616\#n16. Consultation date: 28/05/2020.

OSIPOV, Yurii. 1978. "Elements and stages of application of the norms of the Soviet civil procedural law. Problems of applying the norms of civil procedural law" In: Scientific Works of the Sverdlovsk Law Institute. Vol. 48, pp. 42-44.

SHCHERBAK, Svitlana. 2011. "The content of the executive process" In: Legal Bulletin of the Ukrainian Academy of Banking. Vol. 2, No. 5, pp. 15-19.

TATSII, Vasyl; HROSHEVYI, Yurii; KAPLINA, Oksana; SHYLO, Olha. 2013. Criminal proceedings. Law. Kharkiv, Ukraine.

THE CASE OF HORNSBY V. GREECE. 1997. Available online. In: https:// zakon.rada.gov.ua/laws/show/ 980_079\#Text. Consultation date: 08/05/2020. 
Nataliia A. Sergiienko, Volodymyr I. Galagan, Zhanna V. Udovenko, Andriy P. Cherneha y Nataliia O. Oblovatska

THE CASE OF ROMASHOV V. UKRAINE (APPLICATION NO. 67534/O1). 2004. Available online. In: https://zakon.rada.gov.ua/laws/show/980 227?find $=1 \&$ text=\%E2\%E8\%EA\%EE\%ED\#w164. Consultation date: 09/05/2020.

THE CASE OF YURIY MYKOLAYOVYCH IVANOV V. UKRAINE (APPLICATION NO. 40450/04). 2009. Available online. In: https:// zakon.rada.gov.ua/laws/show/974_479?find=1\&text=\%E2\%E8\%EA\% EE\%ED\#w1106. Consultation date: 09/05/2020.

ZELENKOVA, Inna. 2017. The procedure for recovery of the debtor's property in the enforcement process. Kyiv University of Law of the National Academy of Sciences of Ukraine Ivano-Frankivsk University of Law named after King Danylo Halytsky. Kyiv, Ukraine. 

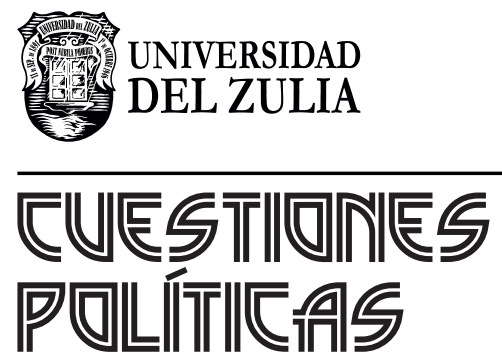

Vol.39 No 68

Esta revista fue editada en formato digital y publicada en enero de 2021, por el Fondo Editorial Serbiluz, Universidad del Zulia. Maracaibo-Venezuela 